\title{
Molecular Screening for PTEN Gene Mutation Among Cigarette Smokers and Assessment of Knowledge of the Link Between Tobacco Use, and Cancer Among Saudi Population
}

\author{
Fawaz D. ALSHAMMARI \\ University of Hail, Department of Clinical Laboratory Science, \\ College of Applied Medical Science, Hail, KINGDOM of SAUDI ARABIA
}

\begin{abstract}
Tobacco use accounts for at least $30 \%$ of all cancer deaths, and $87 \%$ of lung cancer deaths. Therefore, the aim of this study was to screen for Phosphatase and Tensin homolog (PTEN) gene mutation among cigarette smokers and to assess population awareness towards tobacco carcinogenicity among Saudi population. This is a cross-sectional survey involved 2099 Saudi civilians living in Northern Kingdom of Saudi Arabia (KSA). PTEN gene mutation molecular detection was performed for 100 tobacco users, DNA extracted from buccal cells. Out of the 2099, participants, 669/2099(31.8\%) were smokers and 1430/2099 (68.2\%) were non-smokers. Data regarding smoking type and status were available for 399 cases of whom, 229/399 (57.4\%) were currently cigarette smokers, 36/399 (9.2\%) were currently shisha smokers and 134/399 (33.6\%) were ex-smokers. PTEN gene mutations were identified among two current smokers. Cigarette smoking is a public concern in KSA, which requires control strategies. There is no significant correlation between PTEN gene mutation and cigarette smoking.
\end{abstract}

Keywords: PTEN gene mutation, Cigarette smokers, Cancer, Saudi population

ÖZET

Suudi Populasyonunda Sigara içenlerde PTEN gen mutasyonu Moleküler Taraması ve Tütün Kullanımı ile Kanser Arasındaki Bağlantının Değerlendirilmesi

Tütün kullanımı, tüm kanser ölümlerinin en az \%30, ve akciğer kanseri ölümlerinin \%87’sinden sorumludur. Bu çalışmanın amacı, sigara içenlerde Fosfataz ve Tensin homolog (PTEN) gen mutasyonlarının taranması ve Suudi populasyonda tütün karsinojenisitesine yönelik farkındalığın değerlendirilmesidir. Bu, Suudi Arabistan Krallığı'nın kuzeyinde yaşayan 2099 kişinin katıldığı kesitsel bir araştırmadır. Bukkal hücrelerden DNA ekstrakte edilen 100 tütün kullanıcısında PTEN gen mutasyonu moleküler tespiti yapıldı. 2099 katılımcıdan 669 (\%31.8)'u sigara içenlerden ve 1430 (\%68.2)'u sigara içmeyenlerden oluşmaktaydı. Sigara içme tipi ve durumu ile ilgili bilgi bulunan ve 399 kişinin 229 (\%57.4)'u halen sigara içmekteydi, 36 (\%9.2)'sı nargile içmekteydi ve 134 (\%33.6)'ü sigarayı bırakmıştı. PTEN gen mutasyonları, halen sigara içmekte olan iki kişide tespit edildi. Sigara kullanımı Suudi Arabistan'da önemli halk sağı̆ğı sorunudur ve kontrol stratejleri gerektirmektedir. PTEN gen mutasyonu ve sigara kullanımı arasında anlamlı bir korelasyon saptanmamıştır.

Anahtar Kelimeler: PTEN gen mutasyonu, Sigara içenler, Kanser, Suudi populasyonu 


\section{INTRODUCTION}

Cigarette smoking is a global health concern causing diverse diseases including cardiovascular disease and various cancers comprising those of the respiratory, digestive, and genitourinary systems, etc. ${ }^{1,2}$ Tobacco use is globally influenced socioeconomic factors. ${ }^{3,4}$ In the developed world, a significant opposite association between socioeconomic status and smoking habit occurs. The poorest and minimally educated individuals are more likely to smoke than others. ${ }^{5}$

Worldwide, the prevalence rates of cancer greatly varies, according to the presence of a certain risk factors, such as environmental exposure to carcinogens and the life style adopted. It is well-known that, more than $30 \%$ of cancer deaths could be prevented by modifying or escaping key risk factors, comprising; tobacco use, obesity, unhealthy diet, lack of physical activity, alcoholic abuse, urban air pollution, and indoor smoke from household use of solid fuels. ${ }^{6,2}$

Raise of cancer awareness has prospective impacts on cancer control. Knowledge of potential carcinogenic has great contribution in reduction or prevention of exposure to carcinogens including tobacco use. $^{7}$

Phosphatase and Tensin homolog (PTEN) gene found on chromosome TEN, is a tumor suppressor gene mutated in a variety of human cancers including oral cancer. ${ }^{8}$ PTEN expression has been down regulated in many malignancies including oral carcinoma. ${ }^{9}$ Loss of PTEN expression is significantly correlated with oral cancer staging, suggesting its significant role in oral cancer development and progression. ${ }^{8}$ Therefore, in this study beside the assessment of awareness levels and cigarette smoking habits among Saudi population, the current study investigated the presence of PTEN gene mutation, as cigarette smoking is one of the risk factors for the development of oral precancerous and cancerous lesions. ${ }^{10}$

\section{MATERIALS AND METHODS}

In this community-based, cross-sectional study, data were collected during cancer awareness campaign which was conducted in Hai'l Region, King- dom of Saudi Arabi (KSA), during the period from October 2014 to January 2015. People were assembled in general public entities (University colleges, Health centers, Community gatherings), then were invited to fill a questionnaire about tobacco habits and other information regarding their attitudes towards the relationship between tobacco use and cancer.

Buccal cells were collected by scraping buccal mucosa for subsequence molecular analysis of PTEN gene mutation. PTEN gene mutation was demonstrated using Polymerase Chain Reaction (PCR).

\section{DNA Extraction}

\section{Cell's DNA Extraction Steps}

Cell lysis: Buccal scraped cells were mixed in preservation solution and placed in a water bath for one hour at $50 \mathrm{C}$. Then $4 \mathrm{ml}$ of a mixture $(2 \mathrm{ml}$ cells plus $2 \mathrm{ml}$ storage solution) was placed in a $15 \mathrm{ml}$ centrifuge tube. One $\mathrm{ml}$ of lysis buffer was added, as well as $10 \mathrm{ul} \mathrm{RNaseA}$ solution $(10 \mathrm{mg} / \mathrm{ml})$. Then incubated at room temperature for 10 minutes then exposed for high-speed vortexing for 10 seconds. Then $1.7 \mathrm{ml}$ was added to the above solution (impurity precipitation lysis mixture). Vortex at high speed 25 seconds. Centrifuged at $8,000 \mathrm{xg}$ for 5 minutes. Impurities and protein precipitation in the bottom of the tube formed a dense precipitate. Less dense protein precipitation was placed on ice for 5 minutes, then step 4 was repeat.

\section{DNA Precipitation}

Carefully the supernatant (containing DNA) was transferred to a new $15 \mathrm{ml}$ centrifuge tube. Careful was paid not to touch the bottom of the tube precipitation. Five $\mathrm{ml}$ of isopropanol was added and mixed gently inverted 50 times (sometimes the precipitation were seen). Centrifugation at 2.500 RPM was performed for 3 minutes, this time in the bottom of the tube the white precipitate DNA was seen. Supernatant was discarded and up sided down on absorbent paper to dry as possible. Adding $5 \mathrm{ml} \mathrm{70 \%} \mathrm{ethanol,} \mathrm{the} \mathrm{DNA} \mathrm{pellet} \mathrm{was} \mathrm{rinsed}$ several times upside down. Then was centrifuged at 2.500 RPM for 1 minute, the supernatant was carefully decanted. After tapping on absorbent paper upside down a few times in order to control dry residual ethanol. 


\section{DNA Dissolved Hydration}

Adding 250 $\mu \mathrm{l}-400 \mu \mathrm{l}$ DNA lysate rehydrated dissolved DNA precipitation, then mixed and placed at $65^{\circ} \mathrm{C}$ and incubated for 30-60 minutes, then at room temperature or overnight at $4^{\circ} \mathrm{C}$ to be rehydrated DNA, the intermediate wall from time to time to help flick rehydrated DNA. DNA for storage of at $2-8^{\circ} \mathrm{C}$.

The program used for amplification at the thermal cycler (Eppendorf - Master cycler) was: a one-step cycle of pre-denaturation at $94^{\circ} \mathrm{C}$ for five minutes; 30 three-step cycles - denaturation at $94^{\circ} \mathrm{C}$ for 30 seconds, annealing at $55^{\circ} \mathrm{C}$ for 30 seconds and elongation at $72^{\circ} \mathrm{C}$ for a minute; and an additional 5 -minute cycle of elongation at $72^{\circ} \mathrm{C}$. The purification success, a total of $5 \mathrm{ul}$ of the purified samples were visualized in $2 \%$ agarose gel.

\section{DNA Quantification}

To evaluate the DNA quantification after DNA extraction, we had analyzed DNA quantity using a NanoDrop spectrophotometer.

PTEN was detected by PCR using: forward: ACCTGTTAAGTTTGTATGCAAC; Reverse: CTTTCCAGCTTTACAGTGAA

\section{Statistical Analysis}

Statistical analysis was performed by proportion. The SPSS software (version 16) was used for statistical analysis.

Ethical consent: A written informed consent was acquired from each respondent, ensuring strict anonymity. This in addition to the fact that, the author followed the tenants of the Declaration of Helsinki.

\section{RESULTS}

This study investigated 2099 participants of whom $669 / 2099(31.8 \%$ ) were smokers and 1430/2099 $(68.2 \%)$ were non-smokers, but living with smoker (passive smokers). Of the 2099, 1408/2099(67\%) were males and 691/2099(33\%) were females, giving males' females' ratio of 2.04: 1.00. Data regarding smoking type and status were available for 399 cases of whom 363/399 (90.8\%) were cigarette smokers and the remaining 36/399 (9.2\%) were shisha smokers. Of the 363 cigarette smok-

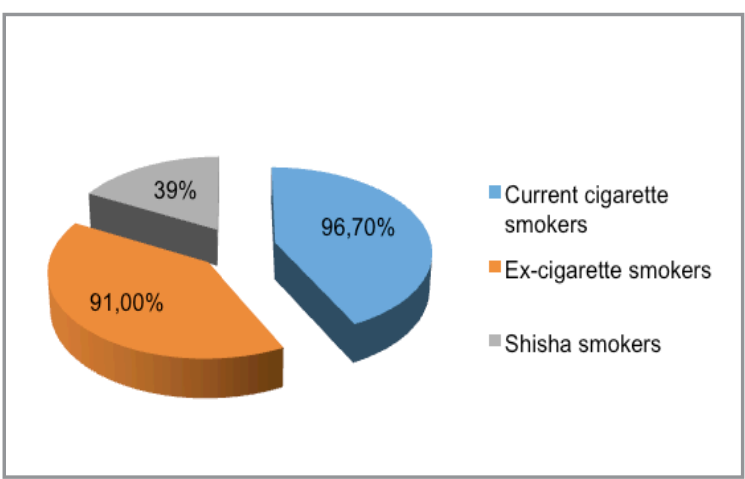

Figure 1. Description of the study subjects by smoking type and status

ers, 229/636 (63.1\%) were current smokers and 134/363 (36.9\%) were ex-cigarette smokers, as indicated in Figure 1. Of the 229 current smokers, $104 / 229(45.4 \%)$ were males and 125/229 (54.6\%) were females.

Out of the 669 smokers, $647 / 669$ (96.7\%) were males and 22/669 (3.3\%) were females. Of the 134 persons who quit smoking, 122/134 (91\%) were males and 12/134 (9\%) were females. Of the 1430 individuals living with smokers, 761/1430 $(53.2 \%)$ were males and 669/1430 (46.8\%) were females. Of the 36 shish smokers, 14/36 (38.9\%) were males and 22/36 (61.1\%) were females, as indicated in Table 1, Figure 2.

Regarding the duration of the smoking, data were available for 415 individuals. The great majority of smokers smoked for duration of less than 5 years, constituting 207/415 (49.9\%), followed by 6-15 years, 16-30 years and more than 31 , representing 156/415 (37.6\%), 49/415 (11.8\%) and 3/415 $(0.7 \%)$, as indicated in Figure 3.

When asking them whether cigarette smoking can cause cancer, 322 of the smokers have answered this question of whom, 249/322 (77.3\%) believe that smoking can cause cancer and the remaining $73 / 322(22.7 \%)$ have declared that there is no relation between smoking and cancer.

Of the 100 cigarette smokers investigated for PTEN gene, PTEN gene mutations were identified among two (2\%) current smokers. 


\begin{tabular}{|llll|}
\hline $\begin{array}{l}\text { Table 1. Distribution of the study population by smoking sta- } \\
\text { tus and type. }\end{array}$ & Males & Females & Total \\
\hline Variable & 647 & 22 & 669 \\
\hline Smokers & 104 & 125 & 229 \\
Current cigarette smokers & 122 & 12 & 134 \\
Ex-smokers & 14 & 22 & 36 \\
Shish smokers & 761 & 669 & 1430 \\
Passive smokers & & & \\
\hline
\end{tabular}

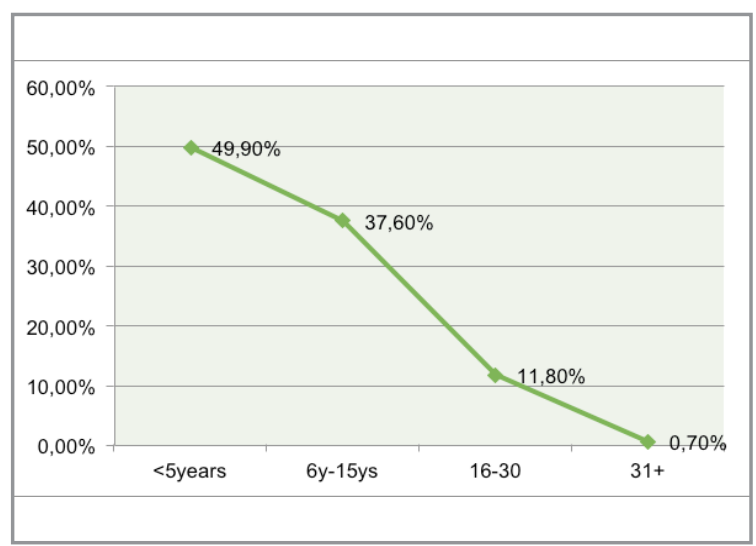

Figure 3. Description of the smokers by duration of smoking in years.

\section{DISCUSSION}

There are sufficient evidences for the strong association between cigarette smoking and various cancers, including those of the nasal cavities and paranasal sinuses, nasopharynx and oral. ${ }^{11,12}$ Assessment of cancer awareness level among a particular community setting is important step toward cancer prevention and control. Such initiatives give the policy makers and health care providers a chance to understand the importance of the interventions and do what is possible to get the desired outcomes. However, this study has three dimensions; firstly, assessed the burden of tobacco smoking among Northern Saudi population; secondly evaluated the level of awareness toward tobacco carcinogens; thirdly investigated the possibility of PTEN gene mutation as an indicator for early car-

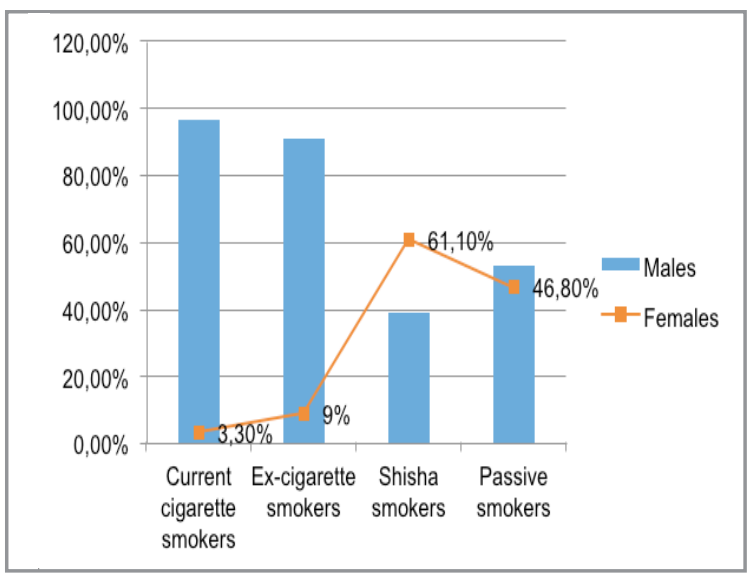

Figure 2. Description of the study population by smoking status and type.

cinogenesis particularly in oral.

Regarding the issue of tobacco use, $31.8 \%$ were found smokers with males more than females. However, similar findings have been previously reported from different part of Saudi Arabia. A review in this context has collected a useful literature on the epidemiology, consumption, trade, control, prevention, and treatment of tobacco smoking in Saudi Arabia. The prevalence of smoking in Saudi Arabia was found ranging between 2.4 and $52.3 \%$ (median $=17.5 \%)$. Among school students, the prevalence rates ranged from 12 to $29.8 \%$ (median $=16.5 \%$ ), among university students from 2.4 to $37 \%$ (median $=13.5 \%)$, and among adults between 11.6 and $52.3 \%$ (median $=22.6 \%$ ) and $25 \%$ in elderly individuals. The prevalence of smoking in males ranged from 13 to $38 \%$ (median $=26.5 \%$ ), whereas, in females it ranged from 1 to $16 \%$ (median= 9\%). ${ }^{13}$ However, some of the reported prevalence rates were relatively lower than the findings in this study. In a study investigated the status of tobacco use among middle schools students in Jeddah, Saudi Arabia and the factors leading to tobacco use, the prevalence of tobacco use among students was $9.72 \%$ with a significant difference between sexes (12.43\% for boys and $6.65 \%$ for girls). ${ }^{14}$ These studies indicate that tobacco smoking is prevalent in different parts of KSA and among different age groups the Saudi population. Moreover, the prevalence of tobacco smoking is greatly higher among males than in females at different ages.

In regard to the evaluation of the level of awareness toward tobacco carcinogens and when ask- 
ing smokers whether cigarette smoking can cause cancer or not, $77.3 \%$ of the smokers believed that smoking can cause cancer and the remaining $22.7 \%$ have declared that there is no association between smoking and cancer. In a recent study from the same area, measured the perception of medical student toward tobacco alcohol consumption and its association with cancer, when asking participants about the relationship between cigarette smoking and cancer, $8.2 \%$ disagreed and the remaining $91.8 \%$ have agreed that smoking can cause cancer. ${ }^{15}$ This relatively higher level of awareness compared to the present study might be attributed to the fact that all of the participants in the later study ${ }^{15}$, were medical students.

However, around $30 \%$ of cancer cases could be prevented by amending lifestyle and avoiding the well-known risk factors. Approximately 1/3rd of cancer cases could be reduced if there is high level of awareness towards the common risk factor and if patients are detected at an early stage of cancer. ${ }^{16}$ Cancer prevalence rates greatly differ worldwide, according to the existence of a particular risk factors, such as environmental exposure to carcinogens and the life style adopted. Moreover, it was found that pictorial health warnings on cigarette packages were significantly associated with increased awareness of smoking-related health hazards and behavior amendment. ${ }^{17}$ Exposure to tobacco advertising, promotion, and sponsorship (TAPS) is found to be linked to the initiation and continuation of smoking among young individuals. The World Health Organization (WHO) Framework Convention on Tobacco Control (FCTC) recommends countries to prohibit all forms of TAPS. A number of countries have implemented partial bans covering direct advertising in media. Nevertheless, a small number of countries have adopted inclusive bans on all types of direct and indirect marketing. To evaluate improvement concerning elimination of TAPS and the level of awareness of TAPS among individuals aged $\geq 15$ years, CDC used data from the Global Adult Tobacco Survey (GATS) collected in 14 countries during 20082010. Awareness of any TAPS ranged from $12.4 \%$ in Turkey to $70.4 \%$ in the Philippines. In the four countries where awareness of TAPs was $\leq 15 \%$, three of the countries had comprehensive bans covering all nine channels measured by GATS, and the fourth country banned seven of the nine channels. In 12 countries, more peoples were aware of advertising in stores than advertising via any other channel. Decreasing exposure to TAPS is essential for preventing initiation of tobacco habit by young adults and helps smokers to quit. ${ }^{18}$

The third point in this study is the investigation of PTEN gene mutation. Oral cells were used to test for this mutation, since a number of studies have clarified the strong causal effects of tobacco in etiology of oral cancerous and precancerous lesions. ${ }^{12}$ This in addition to the fact that the relationship between PTEN gene mutation and the development of oral cancer is well established. ${ }^{8}$

Although there are numerous studies on the etiology of oral cancer but the exact pathogenesis still unclear. The major etiologic factors in the development of oral cancer is tobacco use and alcohol consumption. ${ }^{10,19}$ The identification of prognostic and predictive markers is clinically essential, since oral cancer is a group of heterogenous diseases with different biological and clinical features. The current study point out the utility of PTEN in the genesis of carcinoma of oral. Loss of PTEN function occur frequently in oral cancer and other cancers. ${ }^{20,8}$ However, to the best of my knowledge, this is the first study to report that cigarette smoking can be associated PTEN loss in oral cells. Previous studies have showed that loss of PTEN increased remarkably according to disease stage and lymph node metastasis [8]. This study suggests that PTEN may play a vital role in the regulation of tumor development during the various stages of the disease. Nonetheless the exact role of PTEN in the genesis of oral neoplastic changes requires further investigations.

\section{Acknowledgements}

I would like to thank Dr. Ibrahim Ginawi for data analysis and revision of the manuscript and Dr. Gamal Mohmmed Alawad for helping in the collection of data. 
International Journal of Hematology and Oncology

\section{REFERENCES}

1. Office of the Surgeon General. National Center for Chronic Disease Prevention and Health Promotion (U.S.) The health consequences of smoking a report of the Surgeon General. [Atlanta, Ga.]: U.S. Public Health Service, National Center for Chronic Disease Prevention and Health Promotion 2004. http://www.surgeongeneral.gov/library/ smoking consequences (Access date: Jun 2016).

2. Ahmed HG. Survey on Knowledge and Attitudes Related to the Relation between Tobacco, Alcohol Abuse and Cancer in the Northern State of Sudan. Asian Pacific J Cancer Prev 14: 3345-3348, 2013.

3. Bobak M, Jha P, Son N, Jarvis M. Poverty and smoking. In: Oxford medical publications. Jha P, Chaloupka F, editor. Oxford; New York: Oxford University Press, 2000: 41.

4. Ahmed HG, Mahgoob RM. Impact of toombak dipping in the etiology of oral cancer: gender-exclusive hazard in the Sudan. J Cancer Res Ther 3: 127-130, 2007.

5. Wipfli H, Samet JM. Global economic and health benefits of tobacco control: part 1. Clin Pharmacol Ther 86: 263-271, 2009.

6. Ahmed HG and Rezgalla TM. A Study of Lung Epithelial Atypia in Regard to the Effect of Smoking and Traffic-Related Air Pollution in Sudan. Open Lung Cancer J 3: 10-16, 2010.

7. Alshammari FA, Ahmed HG. Assessment of Awareness towards Some Carcinogens in Hail Region, Saudi Arabia. Manage Health 17: 15-18, 2013.

8. Rahmani A, Alzohairy M, Babiker AY, et al. Clinicopathological significance of PTEN and bcl2 expressions in oral squamous cell carcinoma. Int J Clin Exp Pathol 5: 965-971, 2012.

9. Boyle PF, Macfarlane GJ, Maisonneuve P, et al. Epidemiology of mouth cancer in 1989: a review. JR Soc Med 83: 724-730, 1990.

10. Ahmed HG, Idris AM, Ibrahim SO. Study of oral epithelial atypia Among Sudanese Tobacco Users by exfoliative Cytology. Anti Cancer Research 23: 1943-1950, 2003.

11. Sasco AJ, Secretan MB, Straif K. Tobacco smoking and cancer: a brief review of recent epidemiological evidence. Lung Cancer 45 Suppl 2: S3-9, 2004.

12. Ahmed HG. Etiology of oral cancer in the Sudan. J Oral Maxillofac Res 4: e3, 2013. doi: 10.5037/jomr.2013.4203.

13. Bassiony MM. Smoking in Saudi Arabia. Saudi Med J 30: 876-881, 2009.

14. Al Agili DE, Park HK. The prevalence and determinants of tobacco use among adolescents in Saudi Arabia. J Sch Health 82: 131-138, 2012. doi: 10.1111/j.1746-1561.2011.00676.x.

15. Alshammari FD, Khalifa AM, Kosba AA, et al. Assessment of perception and submerge of Medical Students in regard to the link between Tobacco or alcohol use and cancer. Asian Pac J Cancer Prev 16: 2697-2700, 2015.
16. Ahmed HG. Awareness survey on knowledge of microbial infectious causes of cancer in Northern State of Sudan. Asian Pac J Cancer Prev 13: 5497-5500, 2013.

17. Awaisu A, Hagi A, Ashour MA, Kheir N. Pictorial health warnings on cigarette packages in qatar: preimplementation awareness and perceptions of ever-smokers versus neversmokers. Nicotine Tob Res 15: 1765-1772, 2013.

18. Centers for Disease Control and Prevention (CDC). Adult awareness of tobacco advertising, promotion, and sponsorship-14 countries. Erratum in. MMWR Morb Mortal Wkly Rep 61: 365-369, 2012.

19. Ahmed HG, Ebnoof SO, Hussein MO, Gbreel AY. Oral epithelial atypical changes in apparently healthy oral mucosa exposed to smoking, alcohol, peppers and hot meals using the AgNOR and Papaniclaou staining techniques. Diagn Cytopathol 38: 489-495, 2010.

20. Lu QL, Abel P, Foster CS, Lalani EN. Bcl-2: Role in epithelial differentiation and oncogenesis. Human Pathol 27: 102-109, 1996.

\section{Correspondence:}

Dr. Fawaz ALSHAMMARI

University of Hail

College of Applied Medical Science

2440

HAIL / KINGDOM of SAUDI ARABIA

Tel: +966505450842

e-mail: fawazabof@gmail.com 